\title{
Marcin Wicha, Rzeczy, których nie wyrzuciłem, Karakter, Kraków 2017, ss. 192
}

DOI: http://dx.doi.org/10.12775/RF.2018.022

Marcin Wicha jest projektantem, grafikiem, autorem wielu artykułów i książek dla dzieci. Jak przestałem kochać design, książka wydana w 2015 roku, to zapis żałoby po śmierci ojca. Odnajdziemy w niej wiele zabawnych anegdot, wspomnień, scen z życia rodzinnego, dla których tło stanowią przemiany społeczno-polityczne Polski. Wicha skupia się zwłaszcza na zagadnieniu wpływu estetyki PRL-u na mieszkańców tej epoki. Dla jego ojca było szczególnie ważne, aby odnaleźć sposób na przetrwanie w brzydocie minionego ustroju. W książce Rzeczy, których nie wyrzuciłem autor mierzy się z podobnym problemem, tym razem jednak przeżywa śmierć matki. Powraca do tematu estetyki, jej wpływu na przeżywanie i postrzeganie przez nas świata. Zadaje pytania dotyczące naszych relacji z rzeczami, takie jak: jakie przedmioty należące do bliskiej osoby należy pozostawić po jej śmierci? Co trzeba wyrzucić? Co może się jeszcze przydać? Wicha porządkuje, układa, przerzuca rzeczy. Pozbywanie się przedmiotów to dla niego konieczny proces, który stanowi część żałoby. Teraz spokój może zostać osiągnięty tylko dzięki rygorom minimalizmu. Porządkowaniu wydaje się towarzyszyć sekretne pragnienie, by zrozumieć bliską osobę poprzez rzeczy, które po sobie zostawiła.

Chyba nie zastanawiamy się zbytnio nad tym, co mówią należące do nas przedmioty. Przyjrzymy się na przykład popularnym obrazkom Żyda, które wiszą w wielu polskich domach. Wizerunek Izraelity z długą broda, który liczy pieniądze, reprezentuje silnie zakorzenione w polskim folklorze wierzenie o dobrobycie, bogactwie i obfitości. Obrazek wisi zazwyczaj w przedsionku, koniecznie po lewej stronie, przy wejściu. Najlepiej byłoby go jeszcze odwrócić do góry nogami. Taki portrecik łatwo można uznać za antysemicki żart i tym samym dokonać nadużycia. Na podstawie tego obrazka można prześledzić na przykład ideologiczne zmiany, jakie zachodziły w polskim społeczeństwie. Wicha słusznie zauważa, że na skalę masową takie obrazki wieszano na ścia- 
nach od 1983 roku$^{1}$. Ta data jest symptomatyczna, ponieważ lokuje się jeszcze przed wybuchem polskiego kapitalizmu, lecz już po wydarzeniach z marca 1968 roku. Obraźliwy obrazek skrywa więc co najmniej dwie różne polityczne tendencje. Po pierwsze, wizerunek Hebrajczyka to symptom politycznej zmiany związanej z nadzieją na czasy kapitalistycznego dobrobytu, a także przeczucie stopniowego wzbogacania się społeczeństwa. Po drugie, pojawienie się obrazków z Żydami, to gwałtowna reakcja na wydarzenia związane z marcem 1968 roku.

Warto tutaj wspomnieć, że Polska w latach osiemdziesiątych to czas, w którym temat Holocaustu dopiero zaczął się pojawiać. Na tej fali również po raz pierwszy poruszono publicznie kwestię wydarzeń marcowych. Ich skutkiem było wypędzenie ostatnich powojennych Żydów i ich dzieci. Marcin Wicha wspomina, że jego babcia komentowała tę sprawę rozpaczliwie: „i po co ja rodziłam te dzieci?2”. Żydzi, przepędzeni z przestrzeni realnej, symbolicznie musieli do niej jakoś wrócić. Chociażby w formie obrazka na ścianie.

Ten kiczowaty obrazek ujawnia problematykę (nie)zwyczajności przedmiotów, a zwłaszcza codzienność i dostępność ukrytych w nich symboli. Rzeczy, którymi się otaczamy i wśród których przebywamy, nie są bowiem tak niewinne, jak mogłoby nam się wydawać. Przedmioty w pewnym sensie produkują rzeczywistość, a jednocześnie są reakcją na nią. Obrazki, malowidła, bibeloty, a nawet szklanka czy talerz, mogą odwoływać nas do przeszłości poprzez retro design. Mogą też wyznaczać futurystyczny trend, kierując nasz wzrok ku przyszłym wydarzeniom. To coś, co po sobie zostawiamy. W tym sensie obrazek Izraelity w latach osiemdziesiątych symbolicznie woła przepędzonych Żydów, ponieważ realnie za bardzo bali się wrócić. Nie jest więc jedynie smutną reprezentacją antysemickich nastrojów, a zaproszeniem do ich powrotu, do dialogu, do rozmowy o świecie, który dawno temu utracono.

Symbolika przedmiotów w kontekście Rzeczy, których nie wyrzucitem jest pomocna $\mathrm{w}$ rozszyfrowaniu świata, $\mathrm{w}$ jakim dorastał autor książki. Przedmioty mówią tu często więcej niż słowa, ponieważ są dostępne tam, gdzie te drugie zawodzą.

Niemoc mówienia o traumie jest częstym doświadczeniem osób, które ona dotyka. Wspominają o niej również wojenne dzieci, wnuki i prawnuki, które dorastały w charakterystycznej atmosferze milczenia i niepokoju. Wicha również ma poczucie, że mówi zbyt dużo, że popełnia niewybaczalny błąd i zdradza tajemnice ${ }^{3}$. Tłumiony, niewypowiedziany lęk wkrada się w rzeczywistość wielu osób, których przodkowie zostali pokrzywdzeni przez wojnę. Brak poczucia zakończenia, przedłużona ża-

\footnotetext{
M. Wicha, Rzeczy, których nie wyrzuciłem, Kraków 2017, s. 137.

Ibidem, s. 123.

Ibidem, s. 140.
} 
łoba, nostalgia za światem, którego się nie znało, to częste doświadczenia wojennych wnuków, do których zalicza się również Marcin Wicha.

$\mathrm{Na}$ trop dziedziczonej pamięci kieruje nas dwudzielna konstrukcja Rzeczy, których nie wyrzuciłem. Pierwsza część opowiada o utracie matki z perspektywy syna. Druga mówi o utracie żydowskości przez matkę i całą rodzinę. Początek jest bardziej żałobnym wspomnieniem za matka, która nadawała tempo życiu autora. Mniej więcej w połowie książki dowiadujemy się o tym, że dawno temu ${ }^{4}$ wygasły dla niej połączenia z żydowskim światem myśli, uczuć, religii. Wojna zerwała więzi z najbliższymi członkami jej rodziny. Najprawdopodobniej dziadkowie i wuj zginęli $\mathrm{w}$ jakimś bunkrze, zostali wywiezieni lub rozstrzelani ${ }^{5}$. Smutek z tym związany starannie ukrywała. Dystansowała się od świata za pomocą ironii.

Żydowskie pochodzenie jest częścią wielu anegdot. Niektóre z nich to po części zaskakująco aktualne spostrzeżenia, a po części pretekst do subtelnej dygresji dotyczącej obecnego kształtu ideologicznego Polski. Wicha wspomina między innymi czas, w którym pracował w prawicowej gazecie. Szczególnie zapadła mu w pamięć pewna sytuacja, podczas której przyszło mu wytłumaczyć swojemu dziecku kwestię żydowskiej Zagłady. Kiedy opowiadał o tym wydarzeniu w swojej pracy, jeden z pracowników gazety całą jego opowieść skwitował: „Ale wytłumaczyłeś jej, że tego nie zrobili Polacy? ${ }^{6 \prime}$.

W jaki sposób opowiedzieć dziecku o tym, że jedni ludzie mordowali drugich? Joanna Wicha znała odpowiedź na to pytanie. Starannie dobierała słowa, mówiła o Zagładzie prosto i celnie. Skutecznie wyjaśniała również dzieciom zawiłości konfliktów politycznych i długofalowe skutki rasizmu czy przemocy ${ }^{7}$. Jej ciągła potrzeba sporów, stawiania niewygodnych pytań i udzielania drażniących odpowiedzi stała w kontrze do promowanej przez komunistów wizji pierwszego powojennego pokolenia. To pokolenie miało nie spuszczać nosa na kwintę. Mieli się bawić, być szczęśliwi. Być Mikołajkami, czyli beztroskimi wiecznymi dziećmi ${ }^{8}$.

Matka była natomiast świetna w awanturach: Awantury były rodzajami treningu. Bezustannie przeciaganymi grami wojennymi. Badała czas reakcji. Próbowała najwłaściwszej taktyki ${ }^{9}$. Autor nie bez powodu sięga tutaj

4 „Dawno temu...", „Kiedyś...”, „,W tamtych czasach...” - osoby, które odziedziczyły pamięć wskazują często na nieścisłości chronologiczne, które są charakterystyczne dla wielu wojennych opowieści. Ujawnia się tutaj nieciągła praca pamięci, w której brak dat, imion, nazwisk, nazw miejscowości. Te historie zawsze są podziurawione, mają luki.

5 M. Wicha, Rzeczy, których nie wyrzucitem, Kraków 2017, s. 154.

6 Ibidem, s. 147.

7 M. Wicha, Rzeczy, których nie wyrzucitem, Kraków 2017, s. 130.

8 Ibidem, s. 74-76, 134-135.

9 Ibidem, s. 111. 
po wojenną metaforykę. Służy mu ona do tego, by wyrazić podziw dla matki podobny do sposobu, w jaki żołnierz podziwia dowódcę wyższego rangą. Sam o sobie wielokrotnie mówi, że był tylko jej uczniem, że tylko dzięki niej ćwiczył swój charakter, lecz nigdy nie osiągnął jej biegłości w sztuce wojennej. Wspomina też o tym, że matka projektowała doskonałe plany odwrotów. Wszystkie były bardzo dynamiczne, pełne ucieczek pociągiem. Brak w nich miejsca na panikę, jest jednak dużo pośpiechu i chaosu ${ }^{10}$. W myślach przenosiła się do miejsc, do których nie udało się uciec jej rodzinie. Wszystko to są oznaki przebytej, lecz nieprzepracowanej traumy. Jej wyrażenie odbywa się poprzez ciało, które w agonalnym stanie odmawia posłuszeństwa i wyrzuca z siebie angielskie słowa ${ }^{11}$. Matka pod koniec życia mówi więc językiem ucieczki.

Książka Rzeczy, których nie wyrzucitem poucza nas o utracie, która może być przeżyciem estetycznym. Marcin Wicha odsłania przed nami paradoks zniknięcia, który produkuje nadmiar. Po zmarłym pozostaje zazwyczaj sterta przedmiotów, które stają się artefaktami przeszłości, tworząc tym samym pewien wyłom w rzeczywistości i odsyłając nas do świata utraconego. W tym przypadku nadmiar to rzeczy pozostawione, które kiedyś były przedmiotami należącymi do kogoś bliskiego, a teraz stają się częścią naszego świata. Musimy je więc uporządkować, większość trzeba jednak wyrzucić. Takie porządkowanie wzmacnia znaczenie tych, które uznamy za ważne i osłabia wartość tych, które okażą się mniej wartościowe. Waloryzacja może też przebiegać na wielu różnych poziomach. Jak wiele razy oceniliśmy książkę po okładce? Zielone ze złotym napisem. Całe czerwone. Te ze zwierzątkami. Czy wybierzemy te książki, które najbardziej nam się podobają? Porządkowanie przedmiotów staje się nagle narzędziem pamięci podlegającym regułom estetycznym. W tym sensie utrata bliskiej osoby produkuje nadmiar, który może zostać usunięty tylko poprzez kolejną utratę.

Justyna Nowak

Uniwersytet Mikołaja Kopernika, Toruń e-mail:nowak.justyna2@gmail.com

10 Ibidem, s. 134.

11 Ibidem, s. 173. 